\title{
Geoscience, development and the environment
}

This century has been remarkable in many ways. Based on the work of a score of giants early this century, we have developed astounding powers of observation. We can see a distant galaxy, atoms dancing on the surface of a crystal and, soon, we will unravel bio-systems. These advances have been coupled to our new information systems; we almost drown in information. And, via such systems, including television, societal expectations have increased to high levels. All such advances have supported the unwavering growth of human population, growth which continues in most of the world. In the 1940s Aldous Huxley wrote of our 'creed of greed, violence and incomprehension'. But the incomprehension is no longer an excuse for destructive behaviour.

In the past two decades, we have become increasingly aware that these great advances have come at a very large cost to the components of many of our most basic life-support systems, and the future prospect is clouded for a host of species, including our own.

It is so strange. We live on a very unusual planet, yet most humans do not realise that all our resources come from this planetary system and all its organic and inorganic components. If our life on Earth is to continue, a life of quality for all who travel with her, we require quite new approaches to our technologies and. in general, more exact knowledge of how our planet functions and evolves.

Given the prospect of a human population which, even transiently, may reach ten billion next century, the demands on all Earth resources will be vast. There will be must be, a huge development of resources. Can we learn to use our knowledge with wisdom? The cost of future mistakes will become increasingly disastrous. Recently Sir Crispin Tickell wrote, "In short, we have most of the means for coping with the problems we face, but are distinctly short on our readiness to use them. Our leaders, whether in politics or husiness, rarely have a time horizon of more than five years."

Just contemplate the coming needs for resources. In the developed world (I hate these terms!) humans currently use 20 tons of rock per person per year, which means $100 \mathrm{~km}^{3}$ for ten billion people. What technologies will provide our energy necds? Surcly they must be based on solar and geothermal resources. Can we provide quality water for ten billion? Will any rivers still flow to the ocean? How will this influence climatc, ocean currents and salinization on the continents? Can we preserve soil of quality, and provide all the minerals for adequate supply of food? As human population moves to cities, the problems of waste management (from plutonium to urban wastes to carbon dioxide) become monsters. The average citizen of the USA produces almost one ton of waste per year.

There must be a much greater appreciation of fluctuations of all types in the Earth system. Such fluctuations require that we have surplus in our food, and water supplies, and appropriate distribution systems.

We must reorganise our sciences to meet the vast future needs of socicty. In the International Union of Geological Sciences, our recent discussions for a revised International Geological Correlation Project have recognized such needs, focused on sustainable development and environmental protection. The new proposal for an International Continental Drilling Project recognizes the need for more exact knowledge of structure and processes in the outer shell of the solid Earth. Our future challenges abound. Can we mine more cleanly, can we use the deep biosphere to clean water resources. can we dispose of carbon dioxide in the crust...?

The problems are global. We must share our knowledge with all concerned with the needed new technologies and future development. Such development must not be left solely to engineers and economists, and we must pay more attention to education at all levels in the global society. There is a great question we must all consider: how many humans can live well, and have a joyous experience on our planct? $\square$

\section{The Hutchison Fund}

\section{request for donations}

Dr William W Hutchison, who was both President and Secretary General of IUGS, left a sum of money in his will to establish a fund to help support young geologists from developing countries to travel to International Geological Congresses. The IUGS Executive Committee decided that the IUGS would ask the international geological community to add to this fund, both because the cause is a very worthy one, and also to remember Bill Hutchison, a distinguished geologist, geological leader, and a warm, decent, fine man. Please think seriously of donating to the fund especially if you knew Hutch, but also because the developing world needs capahle young geologists to help guide it into the future. Please send donations to:

\author{
Robin Brett \\ Secretary General, IUGS \\ US Geological Survey \\ 917 National Center \\ Reston, Virginia 22092, USA
}

\begin{abstract}
We would prefer cheques in US dollars, to avoid the high bank charges for converting other currencies, but also welcome Visa and Mastercard (give account number and date of expiry). US residents are reminded that gifts of this nature are tax deductible.
\end{abstract}

